\title{
Optimization of spectrophotometric method for determination Nattokinase activity in dietary supplements
}

\author{
Nguyen Thi Dieu Thu', Hoang Viet Dung ${ }^{1}$, Nguyen Thi Hong Ngoc ${ }^{2}$, Vu Thi Thanh An ${ }^{2}$ \\ Mac Thi Thanh $\mathrm{Hoa}^{2}$, Cao Cong Khanh², Tran Hung Son ${ }^{2 *}$ \\ ${ }^{1}$ Vietnam Millitary Medical University, Hanoi \\ ${ }^{2}$ National Institute for Food Control, Hanoi
}

(Received: 06/04/2020; Accepted: 22/6/2020)

\section{Abstract}

Nattokinase is an enzyme with a strong fibrinolytic activity that can be used for preventing thrombolytic diseases. The fibrinolytic activity of the Nattokinase in dietary supplements is determined by spectrophotometric method. In this study, the conditions of the assay were examined and finally optimized as $\mathrm{pH} 8.5$, reaction temperature: $40^{\circ} \mathrm{C}$, and reaction time: 60 minutes. The proposed method was validated and successfully applied to determine the Nattokinase activity in 10 dietary supplements. The results showed that the proportion of measured activity compared to label product activity were within in the range $79.1-98.0 \%$. The effect of herbal compounds and excipients on Nattokinase activity were also surveyed. From the evaluated results and application to commercial samples, this method will be a valuable contribution to quality control of dietary supplement products containing Nattokinase.

Keywwords: Nattokinase, dietary supplements, fibrinolytic activity, spectrophotometric method.

\section{INTRODUCTION}

Nattokinase is an enzyme extracted from a popular Japanese food called "Natto". Natto is a traditional food made of soybean fermented with Bacillus subtilis. Natto has been used as a folk remedy for diseases of the heart and blood vessels for hundreds of years. Common names for the Nattokinase include natto extract, subtilisin NAT and fermented soybeans. It belongs to the serin protease family, the sequence of its primary structure includes 275 amino acid residues, with the molecular weight of 27.778 Dalton. It has strong fibrinolytic properties. It remains stable between from $\mathrm{pH}$ from 6.0 to 12.0 but loses its fibrinolytic activity quickly if $\mathrm{pH}$ is less than 5.0 or temperature higher than $50^{\circ} \mathrm{C}$ [1].

Nattokinase is a fibrinolytic enzyme, meaning that it breaks down fibrin, an insoluble protein produced by the conversion of fibrinogen (a protein in the plasma of blood for clotting) by thrombin (a blood-clotting enzyme). It degrades fibrin clots both directly and indirectly. It degrades fibrin directly in clot lysis assays with activity comparable to plasmin and degrades fibrin indirectly by affecting plasminogen activator activity. It helps in normal blood circulation, blood flow, blood viscosity. It also supports the body's normal blood-clotting mechanism, supports the body's production of plasmin, which reduces fibrin and helps to maintain normal blood pressure level. It is also used for pain, fibromyalgia, chronic fatigue syndrome, endometriosis, uterine fibroids, muscle spasms, tissue oxygen deprivation, infertility, cancer [1-5].

The determination method for fibrinolytic activity is very important in the research of Nattokinase. Astrup \& Mullerts (1952) develop the Fibrin plate method to measure the fibrinolytic method. This method includes a simulated thrombus artificially formed by fibrinogen

${ }^{*}$ Corresponding author: Tel 0389811395

Email: tranhungson113@gmail.com 
and thrombin in a petri dish. The position of the area on the petri dish that has contact with fibrinolytic enzyme will generate a lytic circle, which stands for the fibrinolytic activity of the enzyme applied. Then, a standard enzyme is used to create a standard curve in order to compare and calculate the activity of the. The serological plate was developed from a fibrin plate assay for determining the activity of nattokinase. The serological plate method was based on the maximum absorbance of fibrin at $655 \mathrm{~nm}$ in visible light $\left(\mathrm{OD}_{655}\right)$, and the absorbance intensity is decreasing along with the fibrin lyses [6]. Clot Lysis Time (CLT) was modified from Astrup's method. Thrombus can be generated in vitro, and the time used for dissolving the preformed thrombus is recorded as CLT, which has a good linear relationship with the logarithm of enzyme concentration within the range of $10-70 \mu \mathrm{g}$ [7].

Ultraviolet spectrophotometry method is a relatively new method for Nattokinase activity determination indirectly through the estimation of its hydrolysate. After the fibrinolytic reaction, the $\mathrm{OD}_{275}$ of soluble hydrolysate products of Nattokinase are measured and compared to the standard units [6]. This method is not affected by external factors and it has been demonstrated to be an accurate and sensitive method, so we chose spectrophotometric method for this study.

Nowadays, dietary supplements which improve brain function are becoming more and more popular and diverse. In these products, Nattokinase is often supplemented with herbal compounds that support brain functions such as Ginkgo biloba, Polyscias fruticose. These compounds as well as the excipients in the product may affect the fibrinolytic activity of the enzyme Nattokinase. Therefore, it is necessary to optimize the method for determination of the Nattokinase activity and study the factors affecting Nattokinase activity in dietary supplements products to provide safe, quality products to consumers.

\section{MATERIALS AND METHODS}

\subsection{Reagents and chemicals}

Nattokinase was provided by Febico, Taiwan; sodium borate decahydrate, sodium chloride, trichloroacetic acid, acetic acid, sodium acetate trihydrate, triton X-100, calcium sulfate dihydrate were purchased from Merck, Germany; fibrinogen and thrombin from bovine plasma were provided by Sigma Aldrich, Singapore; distilled water was obtained from Merck Millipore water purification system.

\subsection{Equipment}

Spectrophotometric analysis was performed using a double beam UV-VIS spectrophotometer UV 2401 (Shimadzu, Japan), fitted with a $10 \times 10 \mathrm{~mm}$ cuvette holder, and scanned within a wavelength range of $198-1.000 \mathrm{~nm}$. Analytical balance (Model ME54E, Mettler Toledo, Switzerland), pH meter (Model S220, Mettler Toledo, Switzerland), centrifuge (Model Z326K, Hermle, Germany), water bath (Model WNB22, Memmerts, Germany) were among the equipment employed for the study.

\subsection{Methods}

\subsubsection{Fibrinolytic activity assay}

Nattokinase was dissolved and diluted with diluent solution ( $2 \mathrm{mM}$ of calcium sulfate dihydrate plus $10 \mathrm{mM}$ of sodium chloride and $0.005 \%$ Triton X-100). For both sample and blank tubes, incubate $1.4 \mathrm{~mL}$ of $50 \mathrm{mM}$ sodium borate buffer with $0.4 \mathrm{~mL}$ of $0.72 \%$ Fibrinogen solution in $5 \mathrm{~min}$. Then, add $0.1 \mathrm{~mL}$ of $20 \mathrm{U} / \mathrm{mL}$ thrombin into tubes and mix. After $10 \mathrm{~min}$, add $0.1 \mathrm{~mL}$ Nattokinase solution into the sample tube and incubate for exact time and temperature (to be 
investigated). Add $2.0 \mathrm{~mL}$ of $0.2 \mathrm{M}$ trichloroacetic acid to stop the reaction, add $0.1 \mathrm{~mL}$ Nattokinase solution into a blank tube and incubate for further $20 \mathrm{~min}$. The tubes were centrifuged at $6000 \mathrm{rpm}$ for 5 minutes and the absorbance of supernatants were measured at $275 \mathrm{~nm}$ against distilled water.

The fibrinolytic activity of the Nattokinase was calculated by this formula:

$$
\text { Nattokinase activity }(\mathrm{FU} / \mathrm{g})=\frac{\mathrm{A}_{\mathrm{T}}-\mathrm{A}_{\mathrm{B}}}{0.01} \times \frac{1}{\mathrm{~T}} \times \frac{1}{0.1} \times \frac{\mathrm{V}}{\mathrm{m}} \times \mathrm{D}
$$

Where $\mathrm{A}_{\mathrm{T}}=$ absorbance of sample solution, $\mathrm{A}_{\mathrm{B}}=$ absorbance of blank solution,

$\mathrm{T}=$ reaction times (minute), $\mathrm{V}=$ volume of Nattokinase extractant $(\mathrm{mL})$,

$\mathrm{m}=$ weight of sample $(\mathrm{g}), \mathrm{D}=$ dilution factor.

One unit (1 FU) of Nattokinase activity is defined as the amount of the enzyme which increases the absorbance of the filtrate at $275 \mathrm{~nm}$ by 0.01 per minute under the conditions specified in the procedure.

\subsubsection{Optimization of $p H$}

The enzyme activity was measured in the range of $\mathrm{pH}$ from 5.5 to 10.0 using the standard activity assay procedure at related $\mathrm{pH}$. The optimal $\mathrm{pH}$ was investigated by measuring the fibrinolytic activity after incubating the enzyme solution at $\mathrm{pH} 5.5,7.0,8.5,10.0$ for 60 minutes at $40^{\circ} \mathrm{C}$.

\subsubsection{Optimization of reaction time}

The enzyme activity was measured in the range of time 30 - 75 minutes using the standard activity assay procedure at related incubate time. The optimal incubate time was investigated by measuring the fibrinolytic activity after incubating the enzyme solution for 30, 45, 60, 75 min for 60 minutes in $50 \mathrm{mM}$ sodium borate buffer $(\mathrm{pH} 8.5)$ at $40^{\circ} \mathrm{C}$ in $50 \mathrm{mM}$ sodium borate buffer (pH 8.5).

\subsubsection{Optimization of reaction temperature}

The enzyme activity was measured in the range of $30,40,50,60,70^{\circ} \mathrm{C}$ using the standard activity assay procedure at related temperature. The optimal temperature was investigated by measuring the fibrinolytic activity after incubating the enzyme solution at $30,40,50,60,70^{\circ} \mathrm{C}$ for 60 minutes in $50 \mathrm{mM}$ sodium borate buffer ( $\mathrm{pH} \mathrm{8.5).}$

\subsubsection{Effect of herbal compounds on Nattokinase fibrinolytic activity}

The examined herbal compounds include Ginkgo biloba extract, Polyscias fruticosa extract, White willow bark extract, Rehmannia glutinosa extract, Paeoniae lactiflora extract, Angelica sinensis extract, Wolfiporia extensa extract, Eucommia ulmoides extract, Codonopsis pilosula extract. Prepare the herbal extracts solution in $50 \mathrm{mM}$ sodium borate buffer $(\mathrm{pH} 8.5)$ at a concentration of $10 \%(\mathrm{w} / \mathrm{v})$ to investigate the effect on Nattokinase activity. Mix $1.0 \mathrm{~mL}$ of the enzyme solution with $1.0 \mathrm{~mL}$ of the herbal extracts solution, pre-incubated for $15 \mathrm{~min}$ at $40^{\circ} \mathrm{C}$ then the fibrinolytic activity was determined.

\subsubsection{Effect of excipients on Nattokinase fibrinolytic activity}

The examined excipients include talc, sodium benzoate, calcium carbonate, magnesium stearate, tapioca starch. Prepare the excipients solution in $50 \mathrm{mM}$ sodium borate buffer $(\mathrm{pH} 8.5)$ at a concentration of $10 \%(\mathrm{w} / \mathrm{v})$ to investigate the effect on Nattokinase activity. Mix $1.0 \mathrm{~mL}$ of the enzyme solutions with $1.0 \mathrm{~mL}$ of the excipient solution, pre-incubated for $15 \mathrm{~min}$ at $40^{\circ} \mathrm{C}$ then the fibrinolytic activity was determined. 


\subsubsection{Method application}

The optimized and validated method was applied for determination of the fibrinolytic activity in commercial dietary supplements containing Nattokinase. Measurement of activity was taken in three replicates. The measured activity was compared with labeled activity to estimate the quality of products.

\section{RESULTS AND DISCUSSION}

\subsection{Optimization of $\mathbf{p H}$}

In this study, the $\mathrm{pH}$ of sodium borate buffer solution from 5.5 to 10.0 were examined. The results are shown in Figure 1.

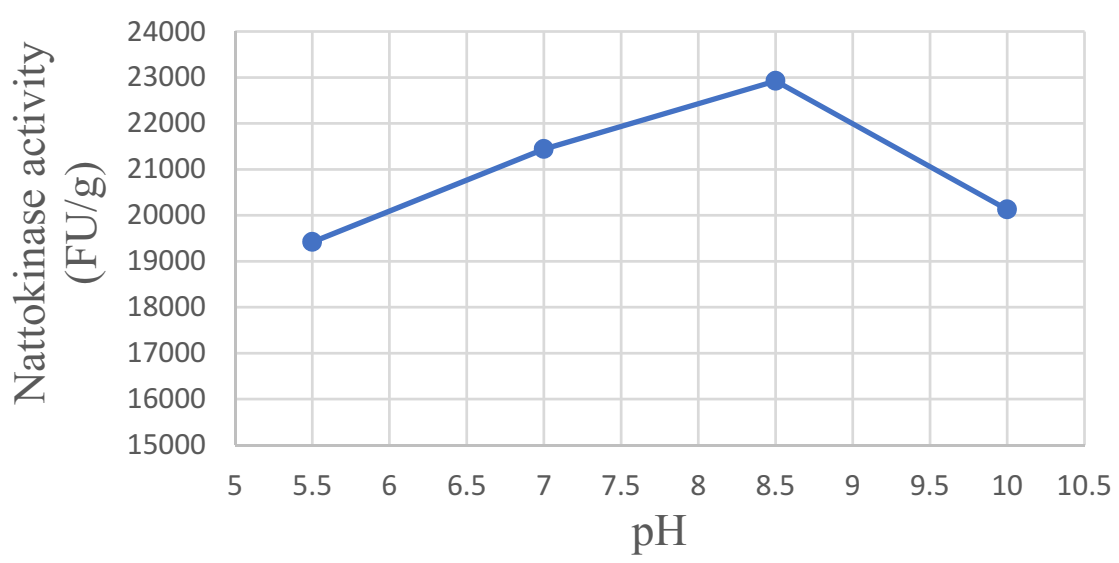

Figure 1. Nattokinase activity at different $p H$ value (5.5 - 10.0)

The Nattokinase activity increased when the $\mathrm{pH}$ increased from 5.5 to 8.5 but decreased when the $\mathrm{pH}$ increased to 10.0 . At $\mathrm{pH} 8.5$, Nattokinase activity was highest and statistically different to those at other $\mathrm{pH}$ values. According to this result, $\mathrm{pH} 8.5$ was the optimal $\mathrm{pH}$ to determine Nattokinase activity.

\subsection{Optimization of reaction time}

In this study, the reaction time from 30 to 75 minutes were investigated. The results are shown in Figure 2.

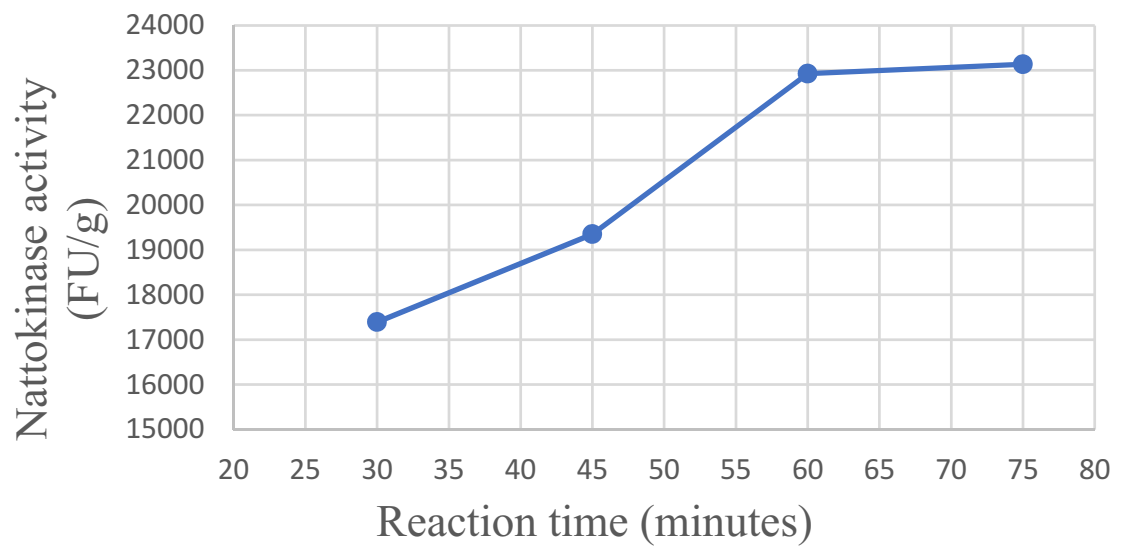

Figure 2. Nattokinase activity at different reaction time (30 - 75 minutes)

The results showed that the fibrinolytic activity of Nattokinase increased when the incubate time increased from 30 to 75 minutes. However, the difference between the Nattokinase activity 
at the reaction time 60 and 75 minutes were not statistically significant. According to these results, the optimal reaction time for the Nattokinase activity assay was 60 minutes to decrease the time of the assay.

\subsection{Optimization of reaction temperature}

In this study, the reaction temperature from $30^{\circ} \mathrm{C}$ to $70^{\circ} \mathrm{C}$ was examined. The results were shown in Figure 3.

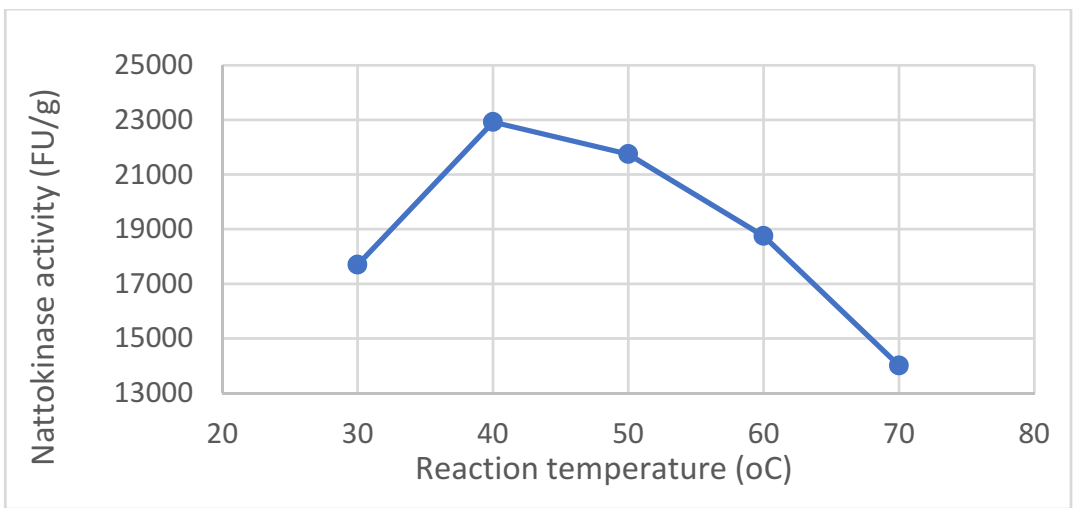

Figure 3. Nattokinase activity at different reaction temperature $\left(30-70^{\circ} \mathrm{C}\right)$

The result showed that the fibrinolytic activity of the Nattokinase was highest at temperature $40^{\circ} \mathrm{C}$ and the activity decreased when the temperature increased from $40^{\circ} \mathrm{C}$ to $70^{\circ} \mathrm{C}$. According to the survey results, the optimal temperature for the Nattokinase activity assay was $40^{\circ} \mathrm{C}$.

\subsection{Method validation}

After examined, the conditions of the assay were selected as $\mathrm{pH} 8.5$, reaction temperature: $40^{\circ} \mathrm{C}$, and reaction time: 60 minutes. The method was validated by determining its specificity, precision, the limit of detection and quantification. Repeatability (RSD \%) was $1.66 \%$ and reproducibility (RSD \%) was $2.770 \%$. The limit of detection (LOD) and the limit of quantification (LOQ) were 5.07 FU/g and 16.7 FU/g. This method was applied to study the effect of herbal compounds and excipients on the Nattokinase activity in dietary supplements.

\subsection{Effect of herbal compounds on Nattokinase fibrinolytic activity}

In this study, we selected 09 herbal compounds which improve brain function to study the affection of these compounds to the Nattokinase activity. The results are shown in Figure 4.

Figure 4. Effect of herbal compounds on Nattokinase activity

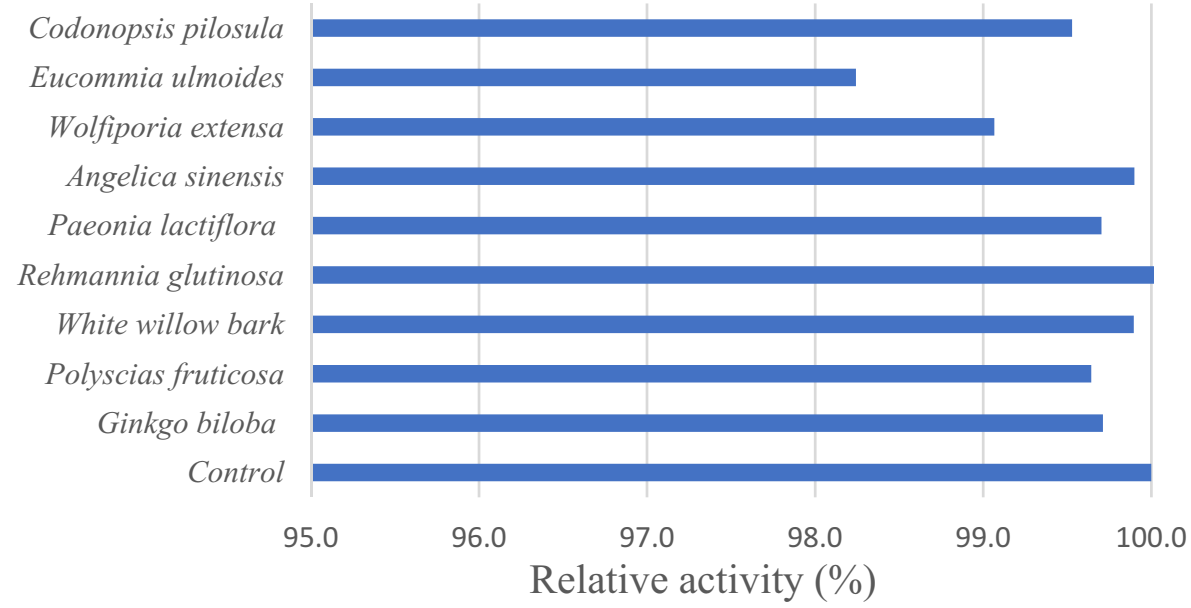


According to this result, the fibrinolytic activity of Nattokinase is not affected by the presence of these herbal extracts at a concentration of $10 \%(\mathrm{w} / \mathrm{v})$. The Nattokinase activity in mixture solutions with herbal compounds was retained at least 98.2\% (compare to the Nattokinase activity of control solution that not mixed with herbal compounds). Thus, it is possible to combine these herbal extracts with the Nattokinase enzyme in dietary supplements without affecting the fibrinolytic activity of the Nattokinase.

\subsection{Effect of excipients on Nattokinase fibrinolytic activity}

In this study, we selected 05 excipients to examine the affection of excipients to the Nattokinase activity, include Talc, calcium carbonate, sodium benzoate, magnesium stearate and tapioca starch. The results are shown in Figure 5.

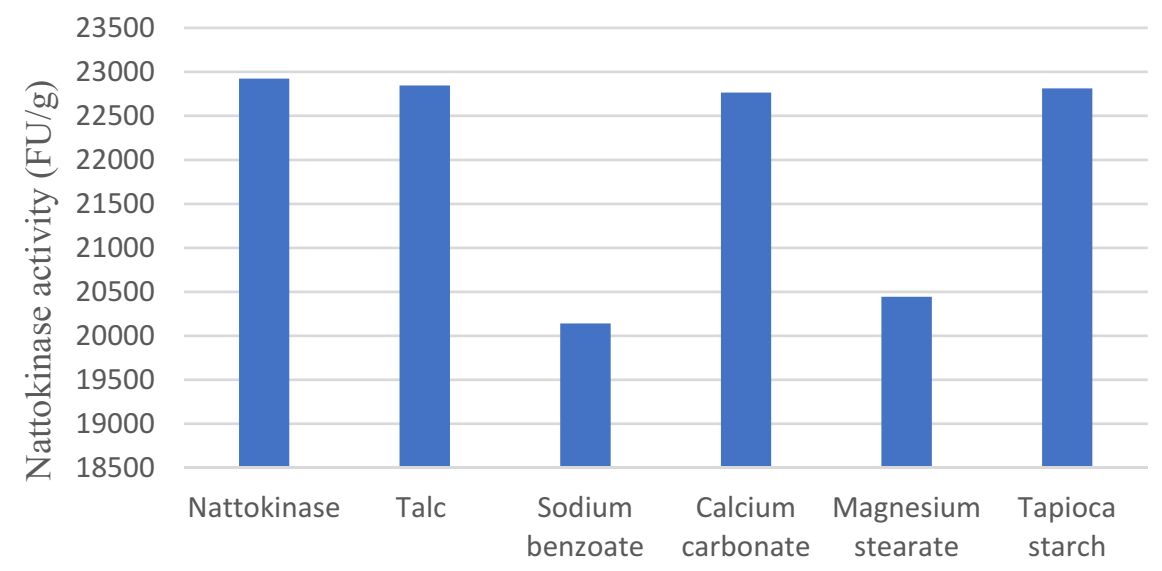

Figure 5. Effect of excipients on Nattokinase activity

The fibrinolytic activity of the Nattokinase was not affected by the presence of talc, calcium carbonate, tapioca starch. However, the Nattokinase activity decreased by the presence of sodium benzoate and magnesium stearate in the mixture. According to this result, the manufacturer should replace sodium benzoate, magnesium stearate by the other excipients in dietary supplements containing the Nattokinase.

\subsection{Analysis of commercial samples}

The currently validated method was applied for the determination of the Nattokinase activity in 10 commercial products. The results of the analysis are presented in Table 1.

Table 1. Analysis of commercial dietary supplements containing Nattokinase

\begin{tabular}{llccc}
\hline Samples & Dosage form & $\begin{array}{c}\text { Measured activity } \\
(\boldsymbol{F U})\end{array}$ & $\begin{array}{c}\text { Labeled activity } \\
(\boldsymbol{F U})\end{array}$ & Percentage (\%) \\
\hline Sample 1 & Hard capsule & $1581 \pm 3.79$ & 2000 & 79.1 \\
Sample 2 & Hard capsule & $823 \pm 3.51$ & 1000 & 82.3 \\
Sample 3 & Hard capsule & $443 \pm 2.79$ & 500 & 88.6 \\
Sample 4 & Hard capsule & $1755 \pm 3.00$ & 2000 & 87.8 \\
Sample 5 & Hard capsule & $163 \pm 3.02$ & 200 & 81.5 \\
Sample 6 & Soft capsule & $294 \pm 4.04$ & 300 & 98.0 \\
Sample 7 & Soft capsule & $94.9 \pm 2.62$ & 100 & 94.9
\end{tabular}




\begin{tabular}{lcccc}
\hline Samples & Dosage form & $\begin{array}{c}\text { Measured activity } \\
(\boldsymbol{F U})\end{array}$ & $\begin{array}{c}\text { Labeled activity } \\
(\boldsymbol{F U})\end{array}$ & Percentage (\%) \\
\hline Sample 8 & Soft capsule & $147 \pm 4.04$ & 150 & 98.0 \\
Sample 9 & Soft capsule & $488 \pm 3.51$ & 500 & 97.6 \\
Sample 10 & Soft capsule & $93.7 \pm 1.01$ & 100 & 93.7 \\
\hline
\end{tabular}

The measured activity was lower than the label product activity in all samples analyzed, the reason might be that Nattokinase is not stable and the loss of activity that have occured. The percentages of measured activity compared to labeled activity for hard capsules were within in the range $79.1-88.6 \%$ while the figure for soft capsules were $93.7-98.0 \%$. The lowest proportion of measured activity compared to label product activity was $79.1 \%$ in sample 1 . However, there were only 10 samples analyzed in this research so it is necessary to analyze a large number of samples to estimate the quality of dietary supplements products containing Nattokinase.

\section{CONCLUSION}

In this study, the conditions of the Nattokinase activity assay method about $\mathrm{pH}$, reaction time and temperature for determination fibrinolytic activity of the Nattokinase were optimized. This method was validated and applied to determine the fibrinolytic activity of the Nattokinase in dietary supplements. The effect of herbal compounds and excipients on Nattokinase activity were also investigated. The results showed that the Nattokinase activity was not affected by examined herbal compounds. However, the fibrinolytic activity decreased by the presence of some excipients, such as magnesium stearate or sodium benzoate.

\section{REFERENCES}

[1] M. Tai and B. Sweet, "Nattokinase for prevention of thrombosis", American Journal of Health System Pharmacy, vol. 63, no. 12, pp. 1121-1123, 2006.

[2] C. Devi, V. Mohanasrinivasan, P. Sharma, D. Das, B. Vaishnavi and S. Naine, "Production, Purification and Stability Studies on Nattokinase: A Therapeutic Protein Extracted from Mutant Pseudomonas aeruginosa CMSS Isolated from Bovine Milk", International Journal of Peptide Research and Therapeutics, vol. 22, no. 2, pp. 263-269, 2015.

[3] E. Selvarajan and N. Bhatnagar, "Nattokinase: An updated critical review on challenges and perspectives", Cardiovascular \& Hematological Agents in Medicinal Chemistry, vol. 15, no. 2, pp. 128-135, 2018.

[4] P. Singh and R. Negi, "Production of fibrinolytic enzyme (nattokinase) from bacillus sp.", Indo American journal of pharmaceutical sciences, vol. 05, no. 1, pp. 379-383, 2018.

[5] Y. Weng, J. Yao, S. Sparks and K. Wang, "Nattokinase: An oral antithrombotic agent for the prevention of cardiovascular disease”, International Journal of Molecular Sciences, vol.18, no.3, pp. 1-13, 2017.

[6] T. Astrup and S. Müllertz, "The fibrin plate method for estimating fibrinolytic activity", Archives of Biochemistry and Biophysics, vol. 40, no. 2, pp. 346-351, 1952.

[7] X. Xin, "Investigations of the industrial compatible aqueous purification techniques an intrinsic stabilizing factors for nattokinase", Open Access Theses and Dissertations, 2016. 


\title{
Tối ưu hoá phương pháp quang phổ hấp thụ phân tử xác định hoạt độ Nattokinase trong thực phẩm bảo vệ sức khoẻ
}

\author{
Nguyễn Thị Diệu Thư ${ }^{1}$, Hoàng Việt Dũng1, Nguyễn Thị Hồng Ngọc², Vũ Thị Thanh An² \\ Mạc Thị Thanh $\mathrm{Hoa}^{2}$, Cao Công Khánh², Trần Hùng Sơn ${ }^{2}$
}

${ }^{1}$ Học viện Quân y

${ }^{2}$ Viện Kiểm nghiệm an toàn vệ sinh thực phẩm Quốc gia

\section{Tóm tắt}

Nattokinase là một enzyme có hoạt tính phân hủy fibrin mạnh và được bổ sung trong các chế phẩm thực phẩm bảo vệ sức khỏe có tác dụng dự phòng, hỗ trợ điều trị bệnh lý huyết khối. Hoạt tính tiêu fibrin của Nattokinase trong thực phẩm bảo vệ sức khỏe được xác định bằng phương pháp quang phổ hấp thụ phân tử. Trong nghiên cứu này, các điều kiện tối ưu của quy trình phân tích đã được khảo sát và xác định, phản ứng được tiến hành ở $\mathrm{pH} 8,5$, nhiệt độ phản ứng là $40^{\circ} \mathrm{C}$ và thời gian phản ứng là 60 phút. Phương pháp xác định hoạt độ Nattokinase đã được thẩm định đạt yêu cầu và áp dụng để phân tích trong 10 mẫu trong thực phẩm bảo vệ sức khỏe. Kết quả phân tích cho thấy hoạt độ Nattokinase trong 10 mẫu thử nằm trong khoảng 79,1 - 98,0\% so với giá trị công bố trên nhãn. Ngoài ra, ảnh hưởng của các loại dược liệu và tá dược có trong sản phẩm tới hoạt tính của Nattokinase cũng được nghiên cứu. Từ kết quả thẩm định và áp dụng phân tích trên mẫu sản phẩm thương mại, cho thấy phương pháp phân tích này có thể áp dụng để kiểm soát chất lượng của các sản phẩm thực phẩm bảo vệ sức khỏe trên thị trường có chứa Nattokinase.

Tù khóa: Nattokinase, thục phẩm bảo vệ sức khỏe, hoạt độ fibrinolytic, quang phổ, hấp thu phân tư. 